\title{
Retention, Effect, and Utility of Tail-mounted Satellite- tracked Transmitters on Golden Eagles
}

Author(s): Alan R. Harmata

Source: Journal of Raptor Research, 50(3):265-275.

Published By: The Raptor Research Foundation

https://doi.org/10.3356/JRR-15-82.1

URL: http://www.bioone.org/doi/full/10.3356/JRR-15-82.1

BioOne (www.bioone.org) is a nonprofit, online aggregation of core research in the biological, ecological, and environmental sciences. BioOne provides a sustainable online platform for over 170 journals and books published by nonprofit societies, associations, museums, institutions, and presses.

Your use of this PDF, the BioOne Web site, and all posted and associated content indicates your acceptance of BioOne's Terms of Use, available at www.bioone.org/ page/terms_of_use.

Usage of BioOne content is strictly limited to personal, educational, and noncommercial use. Commercial inquiries or rights and permissions requests should be directed to the individual publisher as copyright holder. 


\title{
RETENTION, EFFECT, AND UTILITY OF TAIL-MOUNTED SATELLITE-TRACKED TRANSMITTERS ON GOLDEN EAGLES
}

\author{
Alan R. HARMATA ${ }^{1}$ \\ Ecology Department, Montana State University, Bozeman, MT 59717 U.S.A.
}

\begin{abstract}
Studies deploying Platform Transmitter Terminals (PTTs) or Global System for Mobile Communications-GPS (GSM) packages on Golden Eagles have typically used backpack harnesses for attachment despite evidence indicating potential significant negative effects on reproduction and survival. Retention, safety, and utility of tail-mounted PTTs were tested on a sample of Golden Eagles in southwestern Montana. Argos satellite-tracked PTTs of two configurations were attached dorsally or ventrally to the central rectrices of 27 Golden Eagles to study survival. Sixteen packages were known to have been molted or removed (i.e., shed) by the eagle and 13 recovered. Of recovered tail-mounts, six $(46 \%)$ were forcibly removed by eagles; five by males and one by a female. All packages that were forcibly removed were 32-g ventral mounts. Females tended to retain tail-mounts longer than males and dorsally mounted PTTs tended to be retained longer than those mounted ventrally. Eagles tagged in winter retained PTTs the longest. The duration of tail-mounted PTT retention was adequate for analysis of survival and yielded an adult annual survival rate $(86 \%)$ consistent with recent U.S. Fish and Wildlife Service estimates $(87 \%)$. Eight of $13(62 \%)$ territorial adults tagged with PTTs were known to attempt breeding the year they were tracked and six $(46 \%)$ produced young, rates that did not differ $(P>0.23)$ from those of a larger sample of the population surveyed during the same period. Logistic regression analysis of cumulative range size by monitoring duration of four territorial adult eagles with tail-mounted GPS indicated that $99 \%$ of total range was recorded within $140 \mathrm{~d}$ of tracking.
\end{abstract}

Key Words: Golden Eagle, Aquila chrysaetos; Platform Transmitter Terminal (PTT); retention; satellite telemetry; tail-mounted PTT.

\section{RETENCIÓN, EFECTO Y UTILIDAD DE TRANSMISORES SATELITALES MONTADOS EN LAS PLUMAS RECTRICES DE AQUILA CHRYSAETOS}

Resumen.-Los estudios que utilizan Transmisores PTT o Sistemas Globales de Comunicación Móvil-GPS (GSM) montados en individuos de Aquila chrysaetos generalmente utilizan arneses tipo mochila para la instalación de los dispositivos, a pesar de la evidencia que indica posibles efectos negativos significativos en la reproducción y la supervivencia. La retención, la seguridad y la utilidad de los transmisores PTT montados sobre la cola de individuos de A. chrysaetos fueron probadas en una muestra de águilas de esta especie en el suroeste de Montana. Los transmisores PTT con seguimiento satelital Argos con dos configuraciones fueron montados dorsal o ventralmente en las plumas rectrices centrales de 27 individuos de A. chrysaetos para estudiar la supervivencia. Dieciséis emisores fueron mudados o quitados (i.e., desprendidos) por las águilas y 13 fueron recuperados. De los dispositivos recuperados, seis (46\%) fueron quitados por la fuerza por las águilas; cinco por machos y uno por una hembra. Todos los dispositivos quitados por la fuerza fueron dispositivos de 32 gramos montados ventralmente. Las hembras tendieron a retener los dispositivos montados en la cola mayor tiempo que los machos y los transmisores PTT montados dorsalmente tendieron a ser retenidos mayor tiempo que los que fueron montados ventralmente. Las águilas marcadas en invierno retuvieron los transmisores PTT durante un mayor periodo de tiempo. La duración de la retención de los transmisores PTT fue adecuada para realizar un análisis de supervivencia y mostró una tasa de supervivencia anual de adultos $(86 \%)$ consistente con las estimaciones del Servicio de Pesca y Vida Silvestre de los Estados Unidos (87\%). Se supo que ocho de 13 (62\%) adultos territoriales marcados con transmisores PTT intentaron reproducirse el año en el que fueron estudiados y seis $(46 \%)$ sacaron adelante pollos, valores que no difirieron $(P>0.23)$ de aquellos obtenidos en una muestra más grande de la población censada durante el mismo periodo. Los análisis de regresión logística del área acumulativa de campeo obtenida con GPS montados en la cola de cuatro

\footnotetext{
${ }^{1}$ Email address: alan.harmata@montana.edu
} 
águilas adultas territoriales indicaron que el 99\% del área de campeo total fue registrada durante 140 días de seguimiento.

[Traducción del equipo editorial]

Capture and marking studies deploying satellitetracked transmitters (also known as Platform Transmitter Terminals [PTTs]) or Global System for Mobile Communications-GPS (GSM) packages on Golden Eagles have proliferated in recent years. U.S. Geological Survey (U.S.G.S.) Bird Banding Laboratory records indicate only 12 auxiliary marking authorizations for PTTs (or GSMs) on Golden Eagles were issued from 2006 to 2010 (D. Bystrak pers. comm.). However, from 2011 to 2015, auxiliary marking authorizations for PTTs (or GSMs) on Golden Eagles tripled for a total of 48 active authorizations by 2016 (D. Bystrak pers. comm.).

Backpack harnesses (e.g., Buehler et al. 1995) typically have been used to attach PTTs and other transmitter types to eagles. Although some researchers indicated lack of effect of backpack harnesses on eagles (Buehler et al. 1991, Hunt et al. 1996), others reported negative effects, particularly on Golden Eagles (Lockhart and Kochert 1980, Marzluff et al. 1997a, Gregory et al. 2003). More recently, no adult breeding Golden Eagles fitted with backpack PTTs in Sweden in 2012 ( $n=12$ eagles from seven pairs) produced young (Moss et al. 2014). The researchers attributed the total nesting failure of the tagged birds to "local food shortage" but did not address the possibility that failure may have been exacerbated by negative effects of the backpack-mounted telemetry system. Stahlecker et al. (2015) reported $55 \%$ of adult Golden Eagles (including three of seven territorial birds) died within 1 yr of being tagged with a backpack PTT and encouraged "closer scrutiny of possible negative effects of backpack PTTs on Golden Eagles." In an ongoing analysis, Millsap may have detected a decrease in survival in a large sample of juvenile and immature Golden Eagles wearing backpack PTTs (B. Millsap pers. comm.). The evidence suggests backpack telemetry harnesses may negatively affect behavior, reproduction, and survival of Golden Eagles.

As a result, I tested retention, effect on reproduction, and utility for determining survival and range size of tail-mounted PTTs on a sample of Golden Eagles in southwestern Montana. I expected tail-mounted packages would have no or negligible effect on behavior, survival, or reproductive rate of tagged birds. Although Golden Eagles generally retain rectrices about 2 yr (Ellis and Kery 2004, pers. obs.), I anticipated a reduced retention ( $\leq 1 \mathrm{yr}$ ) of rectrices supporting tail-mounted PTT packages but accepted it as a trade-off to maximize the ethic of primum non nocere for eagles included in the study. However, I suspected that retention would at least be adequate to address the primary objective of the marking study, i.e., accurate estimates of survival (Harmata 2015a).

\section{Methods}

Capture and Marking. Golden Eagles were captured as free-flying birds with Coda net launchers (Coda Enterprises, Inc., Mesa, AZ U.S.A.) or padded leg-hold traps (Miner 1975). Eagles were tagged primarily in southwestern Montana roughly between $44.7^{\circ} \mathrm{N}$ (West Yellowstone) and $47.5^{\circ} \mathrm{N}$ (Great Falls), and between $110.8^{\circ} \mathrm{W}$ (Ringling) and $112.3^{\circ} \mathrm{W}$ (Twin Bridges) between February 2011 and January 2015. However, some tagged eagles ranged widely throughout the state and from southeastern Idaho and central Wyoming to northwestern Alaska.

Emphasis was placed on capturing adult Golden Eagles resident in Montana to study survival. Only one member of an adult, mated pair on territory was PTT-tagged. Younger age classes were captured opportunistically or in territories after target adults were tagged. Captured eagles were sexed by size (Harmata and Montopoli 2013) and aged by plumage (Humphrey and Parkes 1959; Table 1 in Bloom and Clark 2001, Ellis 2004). Age classes were juvenile, immature (Basic I and II plumage), subadult (Basic III plumage), or adult.

Golden Eagles were tagged with one of two Argostracked PTT configurations (Fig.1). One was a 32-g, $63.5 \times 22 \times 18 \mathrm{~mm}$, battery-powered Doppler unit (NorthStar Science and Technology, LLC, King George, VA U.S.A.) attached ventrally to central rectrices. The second was a 22-g, $63 \times 20 \times 17 \mathrm{~mm}$, solar-powered GPS PTT (Model 22GPS, Northstar Science and Technology, LLC, King George, VA U.S.A.) attached to central rectrices dorsally to expose solar panels to sunlight. Duty cycles were 6 hr on, $2 \mathrm{~d}$ off for both units. Solar units provided up to six hourly GPS locations daily between 0800 and $2200 \mathrm{H}$ MST with adequate light. GPS units also provided Doppler data. Antennas on both units 
Table 1. Golden Eagles marked with tail-mounted satellite-tracked Platform Transmitter Terminals (PTTs) in southwestern Montana. $\mathrm{N}=$ Nestling, Juv = Juvenile, Imm = Immature, SA = Subadult, Ad = Adult; $\mathrm{L}=\mathrm{Local}, \mathrm{M}=$ Migrant, $\mathrm{R}=$ Resident, $\mathrm{T}=$ Territorial, $\mathrm{F}=$ Floater. $\mathrm{L}, \mathrm{R}, \mathrm{T}$, and $\mathrm{F}$ status all had summer range in Montana. * Indicates eagles likely dead at end date; all others confirmed or likely alive. Failed PTTs were not recovered. Recov $=$ recovered, Unrec $=$ not recovered, Removed indicates PTT forcibly detached by eagle.

\begin{tabular}{|c|c|c|c|c|c|c|c|c|}
\hline \multirow[b]{2}{*}{ EAGLE ID } & \multirow[b]{2}{*}{ AgE } & \multirow[b]{2}{*}{ SEX } & \multirow[b]{2}{*}{ Status/Summer Range } & \multirow{2}{*}{$\begin{array}{c}\text { DATE } \\
\text { TAGGED }\end{array}$} & \multirow{2}{*}{$\begin{array}{c}\text { PTT } \\
\text { PosITION }\end{array}$} & \multicolumn{2}{|l|}{ ACTIVITY } & \multirow[b]{2}{*}{ PTT FATE } \\
\hline & & & & & & END DATE $^{\mathrm{a}}$ & DAYS & \\
\hline Boat Launch & Juv & q & Local & $24 \mathrm{Jul} 2013$ & Dorsal & 24 Sep 2013 & 62 & Failed $^{\mathrm{b}}$ \\
\hline MRCC & Juv & q & Local & 20 May 2014 & Ventral & 14 Sep 2014 & 117 & Unrec $^{c}$ \\
\hline Ringling Girl & Juv & q & Migrant/Alaska & 29 Mar 2012 & Dorsal & 4 Feb 2013 & 313 & Recov $^{\mathrm{d}}$ Molted \\
\hline Smith Trap & Juv & q & Migrant/Alaska & 4 Apr 2012 & Ventral & 21 Aug 2012 & 129 & Unrec \\
\hline Rice Rocket & $\mathrm{Imm}$ & o & Resident & 9 Sep 2013 & Ventral & 6 Apr 2013 & 56 & Recov Removed \\
\hline Bull Sitz & $\mathrm{Imm}$ & 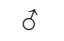 & Migrant/? & 14 Mar 2012 & Ventral & 14 Oct 2012 & 206 & Recov Molted \\
\hline W Bear Crk & SA & 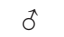 & Resident & 26 Jan 2014 & Ventral & 5 Jun 2014 & 130 & Failed $^{\mathrm{b}}$ \\
\hline AK Dude & SA & $\hat{0}$ & Migrant/Alaska & 1 Feb 2014 & Ventral & $15 \mathrm{Jul} 2015$ & 164 & Unrec \\
\hline E Bear Crk & SA & 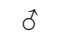 & $?^{\mathrm{f}}$ & 26 Jan 2014 & Ventral & 17 Feb 014 & 22 & Recov Removed \\
\hline Bumble Foot & SA & q & Migrant/British Columbia & 21 Mar 2015 & Ventral & $12 \mathrm{Jul} 2015$ & 113 & Unrec \\
\hline Camp & Ad & 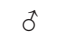 & Territorial & 2 Mar 2011 & Ventral & 6 Jul 2011 $1^{\mathrm{g}}$ & 122 & Unrec $^{c}$ \\
\hline Skinner & Ad & q & Territorial & 28 Feb 2011 & Dorsal & 6 Mar 2011 & 7 & Unrec $^{\mathrm{h}}$ \\
\hline Ringling Gal & Ad & q & Territorial & 17 Sep 2011 & Ventral & 21 Jun 2012 & 278 & Recov Molted \\
\hline Swingley* & Ad & $q$ & Floater & 29 Aug 2011 & Ventral & 11 Jan 2012 & 135 & Unrec $^{\mathrm{h}}$ \\
\hline Yellow Dog & Ad & q & Territorial & 21 Jan 2014 & Ventral & 26 Sep 2014 & 248 & Failed $^{\mathrm{b}}$ \\
\hline Reynolds Crk & Ad & 0 & Territorial & 7 Jan 2012 & Ventral & 7 Mar 2012 & 60 & Recov Removed \\
\hline Bear Canyon & Ad & 0 & Territorial & 10 Feb 2013 & Ventral & 22 May 2013 & 101 & Recov Molted \\
\hline Hot Sprs Crk & Ad & q & Territorial & 31 Jan 2012 & Ventral & 15 Feb 2012 & 15 & Recov Removed \\
\hline Roundup & Ad & q & Floater & 1 Feb 2013 & Ventral & 22 Jul 2013 & 171 & Recov Molted \\
\hline WCM & Ad & $\hat{0}$ & Territorial & 6 Nov 2011 & Ventral & 12 Feb 2012 & 98 & Recov Removed \\
\hline Six Toes & Ad & q & Floater & 21 Mar 2013 & Ventral & 11 Aug 2013 & 143 & Recov Molted \\
\hline Hiline Dad & Ad & o & Territorial & 23 Jan 2013 & Dorsal & 11 Apr 2013 & 78 & Recov Removed \\
\hline Bear Creek & Ad & q & Territorial & 18 Dec 2013 & Dorsal & 11 Jun $2014^{\mathrm{i}}$ & 175 & Unrec Molted \\
\hline Old $\mathrm{Man}^{\mathrm{j}}$ & Ad & $\hat{0}$ & Territorial & 16 Dec 2014 & Ventral & 3 Feb 2015 & 49 & Failed $^{\mathrm{b}}$ \\
\hline Ruby Dude & Ad & 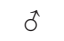 & Territorial & 19 Dec 2014 & Dorsal & 12 Jul 2015 & 205 & Recov Molted \\
\hline Cottonwood & Ad & $\widehat{0}$ & Territorial & 21 Jan 2015 & Dorsal & 20 Jul 2015 & 180 & Unrec $^{c}$ Molted \\
\hline Twala Peak & Ad & q & Migrant/British Columbia & 20 Mar 2015 & Ventral & $20 \mathrm{Jul} 2015^{\mathrm{a}}$ & 124 & Unrec \\
\hline
\end{tabular}

${ }^{\text {a }}$ Sensor data indicated end of movement of PTT.

${ }^{\mathrm{b}}$ PTT failed on eagle.

${ }^{\mathrm{c}}$ PTT failed before recovery possible.

${ }^{\mathrm{d}}$ Recovered in Montana during $2^{\text {nd }}$ vernal migration.

e Last location $166 \mathrm{~km}$ south of Montana.

${ }^{\mathrm{f}}$ PTT removed by eagle before status was definitive.

g Actual or probable shed date, eagle subsequently observed.

${ }^{\mathrm{h}}$ Access denied by landowner.

${ }^{\mathrm{i}}$ Last day PTT observed on eagle post failure.

j Originally banded March 1992.

were $195 \mathrm{~mm}$ long and sutured adjacent to the ventral rachis, and both units were attached with mechanisms to distribute package weight between both rectrices while allowing feathers to spread and contract (Fig. 2). All eagles tagged with tailmounted PTTs were also marked with a U.S.G.S. pop-rivet leg band, and blood and feather samples were collected from some. I suspected that ventrally mounted systems would be retained longer than dorsally mounted systems, mostly due to visual prominence and proximity of the dorsal package, especially when the eagle accessed the uropygial gland during preening. Hence, I invested in fewer solar GPS-capable PTTs.

Eagle Residency and Breeding Status. Behavior and movements of tagged eagles permitted confirmation of residency and mated status. Eagles present within Montana between 15 April and 15 

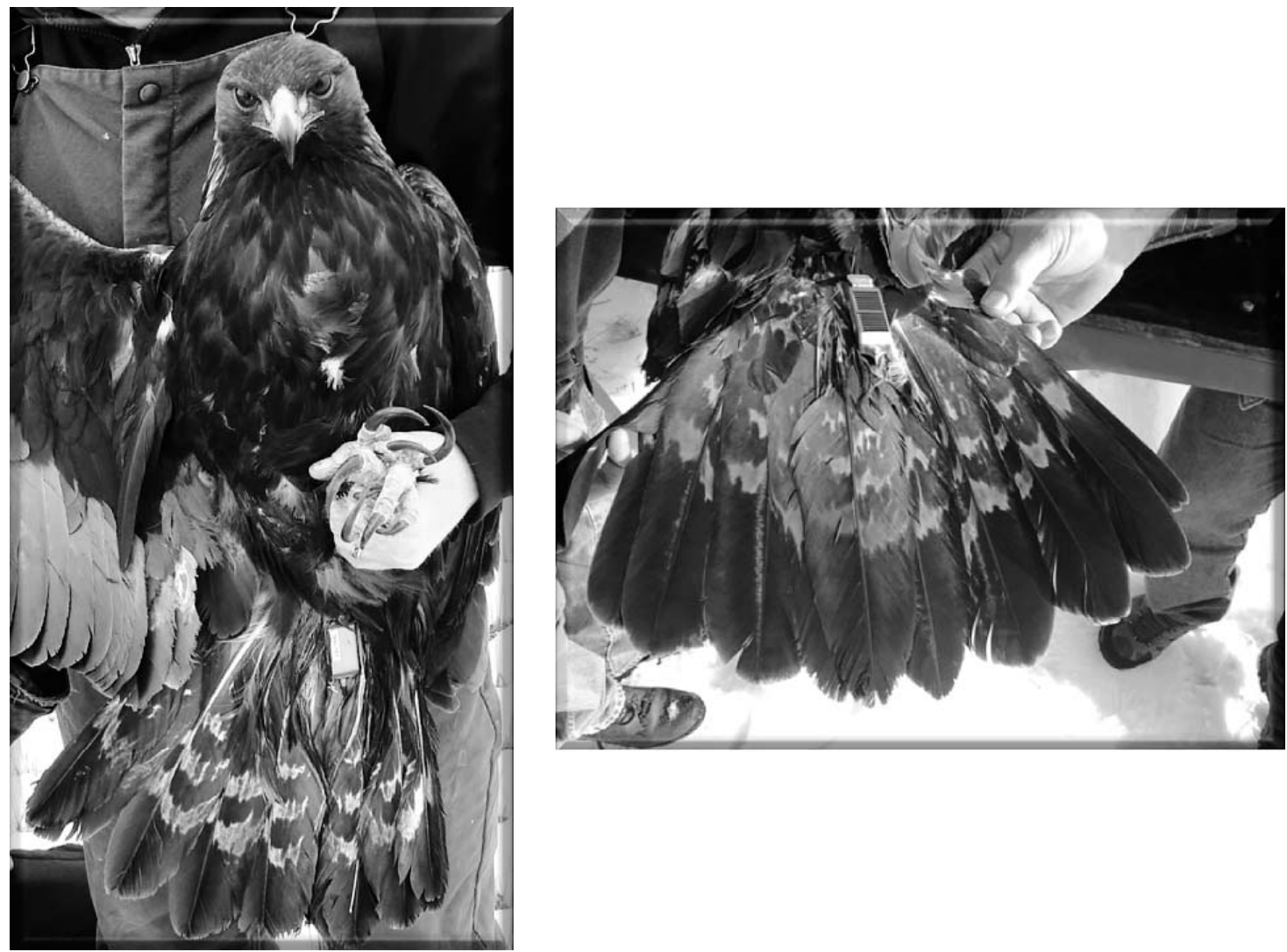

Figure 1. Satellite-tracked Platform Transmitter Terminals on central tail feathers of adult Golden Eagles. Left: 32-g battery-powered Doppler unit on male. Right: 22-g solar powered GPS unit on female.

October were considered residents. Eagles located outside Montana at any time during tracking were considered migrants. Resident adults observed engaged in breeding behavior or commonly associated with nest sites or another adult eagle of distinctly dissimilar size were considered territorial and mated. Resident adult eagles not commonly observed associated with nest sites or another adult eagle of distinctly dissimilar size and ranged widely were considered floaters (Brown 1969, Hunt 1998) and were assumed to be unmated. Nonadult eagles were classified as either resident or migrant based on above criteria.

PTT Recovery and Fate Assignment. Lack of movement of a PTT during one duty cycle as determined by Argos activity sensor data indicated either a dead or debilitated eagle, or a shed (i.e., molted or forcibly removed by eagle) PTT and stimulated recovery effort by vehicle or on foot. At the most recent telemetry location, visual scanning and a Communications Specialists, Inc., AL-1 ARGOS PTT LOCATOR ${ }^{\mathrm{TM}}$ receiver programmed to receive $401.650 \mathrm{mHz}$ frequency with an omnidirectional or two-element, handheld directional antenna were employed during the "on" portion of the PTT's duty cycle. Patience was required when locating PTTs, as signal pulse rate was only $1 / \mathrm{min}$ for Doppler units and $1 / \mathrm{hr}$ for solar units.

Fate (alive/dead) of eagles whose PTTs were recovered was obvious but fate of eagles with PTTs that stopped transmitting data or were unrecovered was not. However, situational criteria associated with cessation of movement or PTT failure (e.g., subsequent observations of eagles of appropriate age/sex at habitual perches and missing central tail feathers) allowed for assessment of fate. Unrecovered PTTs that stopped moving later than early July, especially those in Alaska, were assumed to have been molted by an eagle that continued to survive because mode of Golden Eagle molt occurs in early 

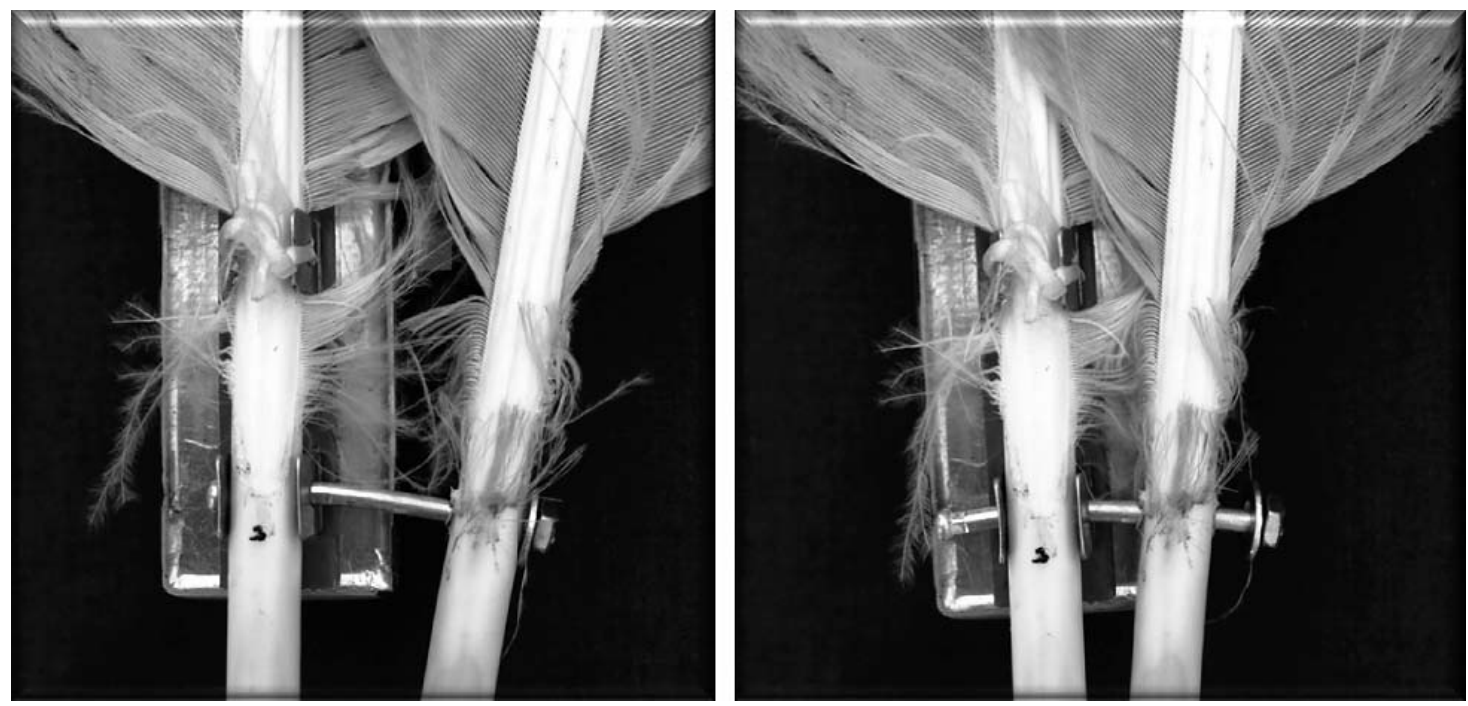

Figure 2. Attachment detail (ventral view) of 22-g solar-powered GPS PTT on molted central rectrices of a Golden Eagle. Note PTT is mounted dorsally to one central rectrix (see Fig. 1). Distal PTT attachment tab is sutured to rachis with veterinary suture material. Proximal tab is attached with modified aluminum 3.2-mm pop-rivet pin extending between calami to distribute weight and permit rectrices to spread and contract to minimize stress on follicles. Pin is approximately $2 \mathrm{~mm}$ in diameter, cut to individual length $(\mathrm{ca} .2 .5-3 \mathrm{~cm})$, and fixed with a flat washer and force-threaded nut secured with cyano-acrylic glue. Left pane shows feathers spread, right pane feathers relaxed. Ventrally mounted PTT attachment (see Fig. 1) is equivalent but accessed dorsally.

summer (Jollie 1947, Ellis and Kery 2004, A. Harmata unpubl. data).

Utility of Tail-mounts in Ranging Studies. Range size as a function of time monitored (days tracked) was analyzed in an attempt to determine if retention of tail-mounted PTTs was adequate to provide representative annual range-size descriptions for territorial eagles. Only GPS-tracked eagles were analyzed because GPS locations (termed "fixes") are inherently more accurate than Doppler fixes. The cumulative proportions of total range size (using minimum convex polygons [MCP; Mohr 1947] in $\mathrm{km}^{2}$ ) per number of days tracked were used to compare area use among four territorial males and one territorial female Golden Eagles tracked by satellite.

Latitude and longitude of each PTT-generated fix were tabulated sequentially in PTT Tracker (GeoTrak 2011) for eagles with $\geq 25$ GPS fixes. Sequential fix locations were exported as .kml files and imported to Google Earth $^{\text {тм }}$ ver. 7.1.2.2041 and displayed. Minimum convex polygons were constructed around peripheral fixes of each plot using the polygon utility in Google Earth. To quantify an eagle's expanding range recorded over time during tracking, polygon files were exported to Earth Point (http://www.earthpoint.us/Shapes.aspx) and MCP area was calculated sequentially at 5-d intervals using the Polygon Area utility.

Because the plots of cumulative proportion of MCP area by tracking time displayed sigmoid shapes typical of logistic curves, a logistic regression model (Hosmer et al. 2013) was developed for each eagle. The dependent variable $p$ for the model:

$$
\frac{e^{\beta_{0}+\beta_{1}\left(\mathrm{D}_{\mathrm{x}}\right)}}{1+e^{\beta_{0}+\beta_{1}\left(\mathrm{D}_{\mathrm{x}}\right)}}
$$

was defined as the cumulative proportion of MCP area detected. The independent variable $\left(D_{x}\right)$ was number of days tracked. Model parameters $\beta_{0}$ (intercept) \& $\beta_{1}$ (slope) were estimated for each distribution using iteratively reweighted least squares techniques (Montgomery et al. 2012) so that models could be compared among eagles.

Data Analysis Considerations. I compared differences in group retention times (d) by parametric procedures. I accepted $P$-values $\leq 0.11$ as indicating statistical difference. This minimized potential type II error due to small sample size. Geometric 
means (GM) also are presented to minimize effect of outliers.

\section{Results}

Eagles Marked. Twenty-seven Golden Eagles were tagged with tail-mounted PTTs (Table 1). Adults made up $63 \%$ of tagged eagles, subadults approximately $15 \%$, immatures $7 \%$, and juveniles approximately $15 \% ; 52 \%$ were females and $48 \%$ were males. Territorial eagles made up $76 \%$ of adults and $18 \%$ of adults were floaters. Migrants composed $22 \%$ of tagged eagles; three summered in Alaska, two in British Columbia and one (identified as "Bull Sitz" [Table 1], after the location where it was captured) likely wintered in the continental United States at latitudes lower than $43^{\circ} \mathrm{N}$ (Table 1). One territorial adult female was previously banded as a 1yr-old, $10 \mathrm{yr}$ prior and $6 \mathrm{~km} \mathrm{NNW}$ of the 2011 capture site ("Ringling Gal," Table 1). An adult male was previously banded as a 1-yr-old, 22 yr prior and $37 \mathrm{~km} \mathrm{NE}$ of the capture site (Harmata and Restani 2015). One territorial adult male was developing both tail feathers adjacent to a central rectrix when captured in December and could not be tagged with a tail-mounted PTT.

Retention of Tail-mounted PTTs. Of 27 PTTs attached to rectrices of Golden Eagles, date of shedding was known for 16, of which 13 (81\%) were recovered (Table 1). All but one recovered PTT were retrieved within one duty cycle of searching. All recovered solar units were located without telemetry by visually searching the coordinates where movement ceased. Four (15\%) PTTs failed or were suspected of failing on the eagle and were not recovered, and two PTTs that ceased movement failed before they could be recovered. Observations of four eagles ("Bear Crk," "Camp," "Ruby Dude," and "N Cottonwood," Table 1) without central rectrices, each within their respective home ranges, soon after PTT movement ceased, confirmed that their PTTs were shed.

The mean length of time tail-mounted PTTs indicated movement was $132.8 \mathrm{~d}(n=27, \mathrm{SD}=84.5$ $\mathrm{d}$, range 7-381 d, GM = $101.0 \mathrm{~d}$ ). Mean length of time eagles retained tail-mounted PTTs where date of molt or removal was confirmed was $143.7 \mathrm{~d}$ ( $n=$ $16, \mathrm{SD}=96.9 \mathrm{~d}$, range $15-381 \mathrm{~d}, \mathrm{GM}=108.6 \mathrm{~d})$. Females tended to retain tail-mounts $(\mathrm{GM}=138 \mathrm{~d})$ longer than males $\left(\mathrm{GM}=94 \mathrm{~d} ; t_{14}=1.7, P=0.11\right.$, Fig. 3) and dorsally mounted PTTs tended to be retained longer $(K=2.5, \mathrm{GM}=181 \mathrm{~d})$ than those mounted ventrally $\left(\mathrm{GM}=86 \mathrm{~d} ; t_{14}=1.76, P=0.09\right.$,
Fig. 3). Attachment techniques evolved and improved over the course of study and later attachments (Fig. 2) tended to be retained longer (Table $1)$.

Of 13 recovered tail-mounts, six (46\%) were forcibly removed by eagles: five by males and one by a female. All packages that were forcibly removed were $32-g$ ventral mounts. Two males broke off the mounting tabs attached to rectrices where they were soldered to the PTT case, and four others broke the supporting feather shafts proximal to the PTT mounting point. Seven $(54 \%)$ of the 13 recovered tail-mounts were found attached to at least one molted rectrix, and six of these seven were found attached to both rectrices. Females tended to molt PTTs in early to mid-summer (June, July) but males were more erratic, possibly related to age, e.g., an adult male molted the PTT in May and immature male molted the PTT in October. The dorsal tailmounted PTT of "Ruby Dude" was molted in July 2015 but not recovered until 7 mo later (Table 1). Initial intensive search at the coordinates of the last GPS locations within $3 \mathrm{~d}$ after movement ceased failed to locate it. The eagle survived, as no carcass was located at the site and an adult was subsequently observed in the home range without central rectrices. I surmised that the molted PTT was not detected on the initial search because a corvid or fossorial mammal cached it soon after it was dropped. It later emerged or was excavated because it was easily found at the same GPS coordinates on a subsequent incidental search several months later. Of eight unrecovered PTTs (four from males and four from females) where situational criteria indicated molt from a live bird, seven occurred in July. One territorial female was still wearing her ventrally mounted PTT when it failed in late September ("Yellow Dog," Table 1).

Survival and Reproduction of Golden Eagles Wearing Tail-mount PTTs. No Golden Eagle wearing a tail-mounted PTT was confirmed to have died during the study. However, one mortality was highly suspected ("Swingley," Table 1). Activity characteristics recorded prior to the abrupt cessation of movement, location, and landowner refusal to allow access to recover the PTT all strongly suggested a dead eagle, likely not as a result of PTT effects or natural causes. All other unrecovered PTTs (Table 1) that ceased movement were likely molted or shed as suggested by location, prior activity, or time of year. Adult annual survival rate estimate obtained during the study from which retention data used 


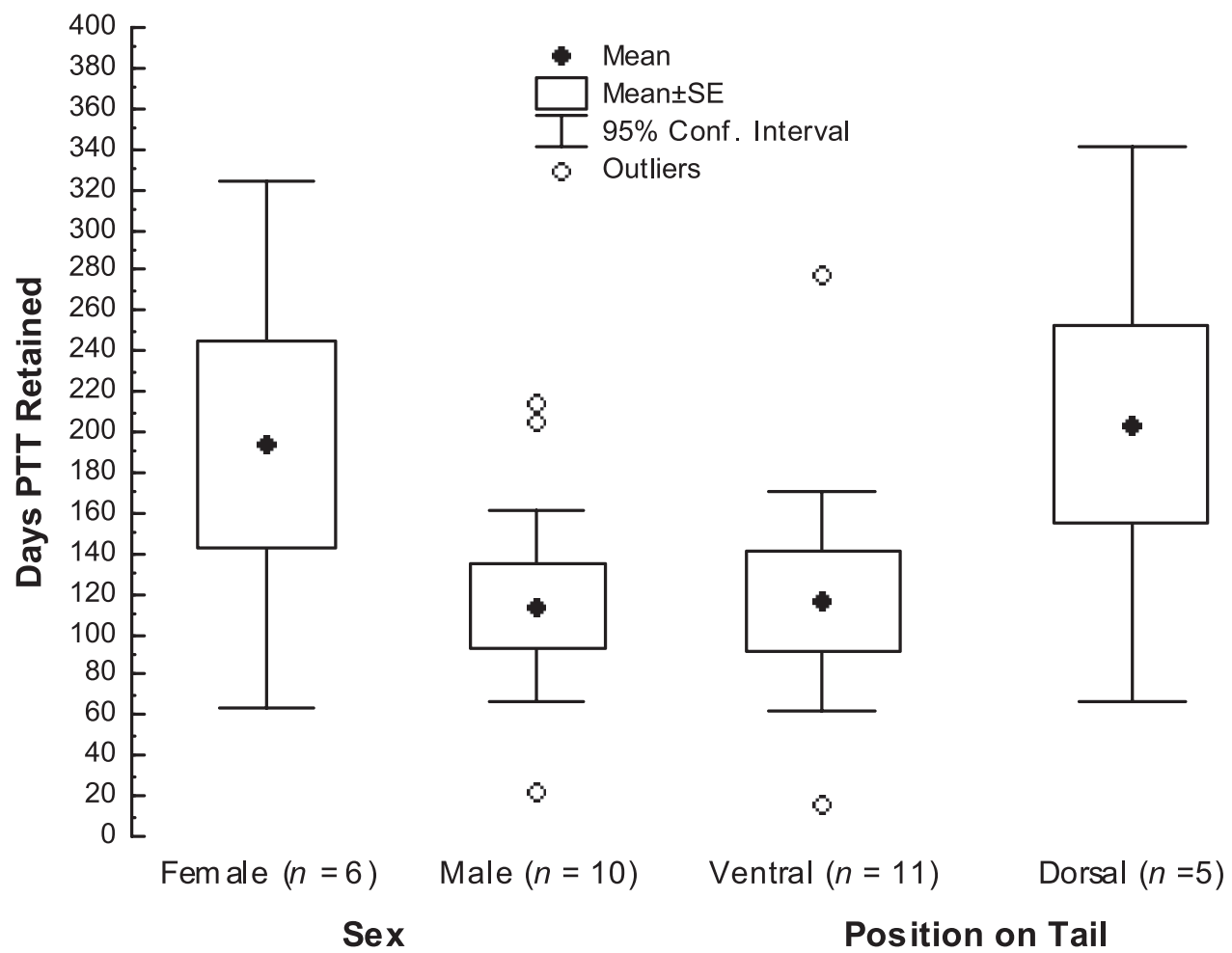

Figure 3. Retention of tail-mounted satellite-tracked Platform Transmitter Terminals (PTTs) by Golden Eagles relative to sex and mounting position on tail. Dorsal mounts were 22-g solar-powered GPS-capable units; ventral mounts were 32g battery-powered Doppler-only units. Sample included one juvenile, two immature, one subadult, and 12 adults.

here were drawn was $86 \% \quad(\mathrm{CI}=60-100 \%)$ (Harmata 2015a).

Of 13 territorial adults tagged with tail-mounted PTTs, eight (62\%; six males and two females) were known to attempt breeding the year they were tracked via telemetry. Two males $(15 \%)$ failed in their breeding attempt and six birds (46\%; four males and two females) produced young. Two females did not attempt to breed, two PTTs were shed (one female) or stopped transmitting (one male) too early in the season to determine breeding activity, and breeding activity was undetermined for one male.

Range Size. Territorial Golden Eagles tracked with GPS-capable PTTs all had $50 \%$ of their total MCP area recorded by $71 \mathrm{~d}$ (Fig. 4). Logistic curves of three of the four GPS-tracked eagles indicated that $99 \%$ of the MCP area was recorded by $140 \mathrm{~d}$ (Fig. 4). However, the slope of the logistic curve of "Hiline Dad" suggests MCP area was still expanding at cessation of tracking (79 d; PTT shed).

\section{DISCUSSION}

Despite a low overall duration of tail-mounted PTT retention (where date of molt or removal was confirmed) of just over 3 mo (but up to $10 \mathrm{mo}$ ), results indicated that tail-mounts were adequate for estimating survival. Adult annual survival rate estimate during this study was consistent with a recent annual survival rate estimate by U.S. Fish and Wildlife Service (U.S.F.W.S.) for after-third-year (i.e., adult) Golden Eagles of $87 \%,(\mathrm{CI}=84-86 \%$; U.S.F.W.S. 2016). Both analyses were conducted in Program MARK (White and Burnham 1999) and U.S.F.W.S. estimates were based on dead-bird band recoveries during 1968-2014.

In addition to a lack of major effect of tailmounted PTTs on survival of adult Golden Eagles, lack of effect on reproduction also was demonstrated by the similarity of tagged adult breeding activity with Golden Eagles included in recent population surveys in southwestern Montana (Harmata 2015b). Specifically, the proportion of territorial adults with PTTs (each representing a pair) attempting to 


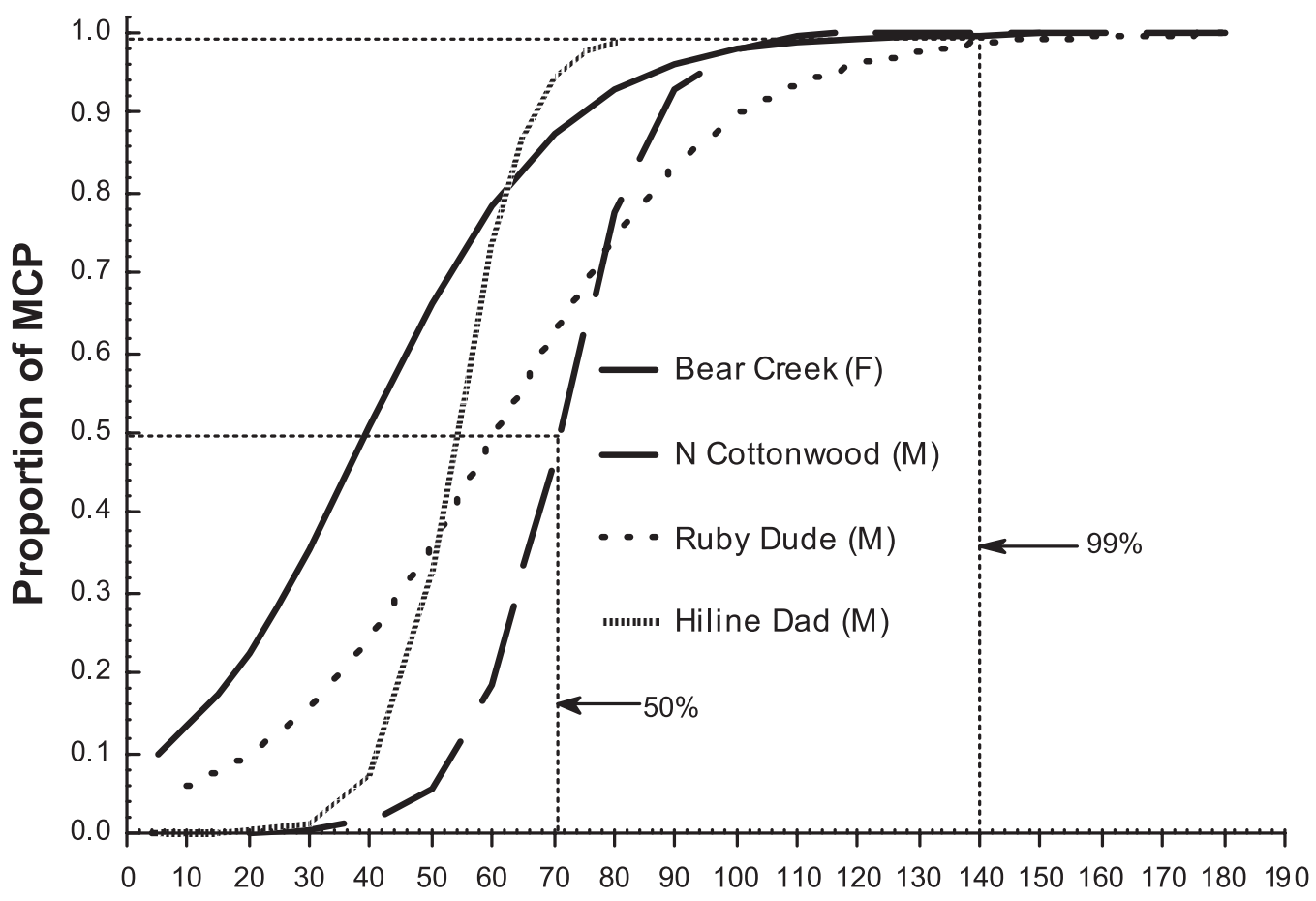

Days Tracked

Figure 4. Logistic regression curves of increasing proportion area of total minimum convex polygon (MCP) homerange area recorded with increasing number of days tracked for territorial adult Golden Eagles tagged with tail-mounted GPS satellite transmitters in southwestern Montana.

breed and breeding successfully (61\% and 46\%) was not different from the proportion of breeding attempts and breeding success of the Golden Eagle population surveyed (231 occupied territories) in southwestern Montana from 2010 to 2015 (69\% and 36\%; $Z<-0.60, P>0.23$; Harmata 2015b).

Some researchers attributed varied effects of backpack-mounted telemetry systems on birds primarily to differences in transmitter mass, shape, and size and their effects on energetics and aerodynamics (Obrecht et al. 1988, Gessaman et al. 1991a, 1991b, Pennycuick et al. 2012). However, Michael et al. (2013) and Peniche et al. (2011) found significant skeletal and soft tissue damage to birds wearing backpack harnesses, inducing Michael et al. (2013) to state "These findings have implications for all avian species deployed with backpack harnesses." I suspect that tolerance of backpack-mounted telemetry systems by Golden Eagles is likewise more directly related to discomfort and restriction of movement imparted by the encumbering harness rather than the PTT hardware configuration. Tolerance is further influenced by biologist talent (or lack thereof) in correctly fitting the harness.

Despite the absence of effects on survival and reproduction and the lack of observed injury or abrasion imparted by tail-mounted PTTs used here, effects were not totally benign. Nearly half of recovered tail-mounts were forcibly removed by eagles and males tolerated packages less well than females. Two males actually broke the PTT casing off the soldered mounting tabs, and the other PTTs forcibly removed were by the eagle breaking the supporting feather shafts proximal to the PTT mounting point. Clearly, they were an annoyance to some eagles, particularly males. I expected that ventral tail-mounts on Golden Eagles were less likely to affect behavior than any mounted dorsally, but, curiously, no dorsal tail-mounted PTT was forcibly removed. Ventral mounts removed by force were possibly due to the weight (32 g) exceeding a 
threshold of tolerance on critical aerodynamic structures (although $<1 \%$ of body mass), physical size of the package (note dimensions, above), or improper attachment creating discomfort or an impediment to preening. Despite the annoyance factor, the effects were not debilitating, injurious, an impediment to reproduction, or fatal.

Over half of tail-mounts recovered had been molted. Females tended to molt PTT supporting feathers in early summer (June, July) but one female wore her PTT from January until at least late September ("Yellow Dog," Table 1). Males were more erratic, possibly related to age and sexspecific intolerance of the package. Adult males shed PTT-supporting feathers in May and July and immature males in April, July, and October. Of unrecovered PTTs where situational criteria indicated shedding from a live bird, nearly all occurred in July. These observations were consistent with those of rectrice molt recorded for captive (Jollie 1947, Servheen 1976, Ellis and Kery 2004) and wild (Bloom and Clark 2001) Golden Eagles. However, Ellis and Kery (2004, Table 1) noted that a captive Golden Eagle molted both rectrices in the same year only twice over $15 \mathrm{yr}$, but six of the seven PTTs recovered with feathers attached had both rectrices, suggesting that PTT mounts used here may have induced abnormal, simultaneous expulsion of both rectrices.

Logistic regression analysis of cumulative MCP area by monitoring duration showed four territorial eagles with tail-mounted GPS PTTs had 99\% of their total range recorded within $140 \mathrm{~d}$ of tracking (Fig. 4). This was approximately the mean length of time eagles retained tail-mounted PTTs where date of molt or removal was confirmed (144 d). MCP ranges of territorial Golden Eagles in Montana $(\bar{x}=$ $1032 \mathrm{~km}^{2}$, Harmata 2015a) were not dissimilar in size to MCP ranges of territorial Golden Eagles in Idaho during the nonbreeding season $\left(\bar{x}=317 \mathrm{~km}^{2}\right.$; Marzluff et al. 1997b) and monthly ranges of Golden Eagles in the Mojave Desert $\left(309 \mathrm{~km}^{2}\right.$; Braham et al. 2015). Idaho habitats were primarily shrub-steppe grassland $\leq 1000 \mathrm{~m}$ in elevation, with moderate topographical relief, and abundant patches of shrubs suitable for lagomorphs (Marzluff et al. 1997a). MCP ranges of territorial Golden Eagles in Montana were also comparable in size to multiyear home ranges of territorial Golden Eagles in Washington and Oregon (Watson et al. 2014), where most nests were $<1000 \mathrm{~m}$ in elevation and eagle prey was dominated by mid- to large-size mammals and upland game birds. However, range sizes were calculated by vastly different methods (c.f., Methods in this study and Watson et al. 2014). Regardless, analysis suggests dorsal tail-mounted PTTs may be adequate for describing annual ranges of resident, territorial Golden Eagles if attached at dates and with techniques recommended here.

Future deployments of tail-mounted PTTs on Golden Eagles should be attached as soon after 1 December as possible (although one adult male had a central rectrix still growing in early December) to promote maximum retention time. However, molt phenology likely varies with latitude and attachment timing may need to be adjusted accordingly. Capture and handling during late autumn-early winter at higher continental latitudes $\left(\right.$ ca. $\left.45^{\circ} \mathrm{N}\right)$ or autumn at lower latitudes $\left(\right.$ ca. $36^{\circ} \mathrm{N}$ ) may be least likely to negatively affect breeding individuals, or to be inhibited by absent/developing rectrices. To minimize any effect of added mass on premature induction of molt of the supporting rectrix, especially on males, PTT mounts should be $\leq 22 \mathrm{~g}$ and include a support brace (pin) from the central mounting rectrix to an adjacent rectrix (not necessarily central) that also permits spreading of feathers (Fig. 2). PTTs should be attached dorsally (Fig. 1) and if technology permits, be of smaller physical size to minimize the "annoyance" factor. Antennas should be attached ventrally, adjacent to the feather shaft on both dorsal and ventral mounted systems to restrict access by the preening eagle.

\section{ACKNOWLEDGMENTS}

This study could not have been conducted without the enlightened cooperation and permission of a vast number of private landowners in southwestern Montana. Beth Madden, Eric Johnston, and John "JT" Thornburg, in addition to assisting in capture and tagging, demonstrated a truly extraordinary ability to locate and recover shed PTTs. Jeremiah Smith, Marco Restani, and Kevin Frey assisted in capture and tagging of eagles. J. Rotella and John Marzluff conducted and interpreted survival analysis and results. Valuable comments on early drafts of this report were provided by Robert "Murf" Murphy and two anonymous reviewers. Thanks to Danny Bystrak and the U.S.G.S. Bird Banding Laboratory for providing auxiliary marking statistics presented here. Funding for the primary study from which these data were drawn was provided by PacifiCorp, as administered through the National Fish and Wildlife Foundation. Research was conducted under Federal Bird Banding Permit \#20357, Montana Dept. of Fish, Wildlife, and Parks Scientific Collectors Permit 201526 and Montana State Univ. IACUC Authority 2013-46. 


\section{LiTERATURE CITED}

Bloom, P.H. AND W.S. CLARK. 2001. Molt and sequence of plumages of Golden Eagles and a technique for inhand ageing. North American Bird Bander 26:97-116.

Braham, M., T. Miller, A.E. Duerr, M. Lanzone, A. Fesnock, L. LAPre, D. Driscoll, AND T. KATZNER. 2015. Home in the heat: dramatic seasonal variation in home range of desert Golden Eagles informs management for renewable energy development. Biological Conservation 186:225-232.

BRown, J.M. 1969. Territorial behavior and population regulation in birds: a review and reevaluation. Wilson Bulletin 81:293-329.

Buehler, D.A., J.D. Fraser, M.R. Fuller, L.S. McAllister, AND J.K.D. SeEgar. 1995. Captive and field-tested radiotransmitter attachments for Bald Eagles. Journal of Field Ornithology 66:173-180.

— - J.K.D. Seegar, And G.D. Therres. 1991. Survival rates and population dynamics of Bald Eagles on Chesapeake Bay. Journal of Wildlife Management 55:608-613.

ELLIS D.H. 2004. Molting in the plumage of juvenile Golden Eagles. North American Bird Bander 29:53-58.

— AND M. KeRY. 2004. Variable retention times for rectrices at different loci in a Golden Eagle. Journal of Raptor Research 38:270-275.

GEOTRAK, INC. 2011. PTT Tracker. Ver 1.0.0.1.4. NorthStar Science and Technology, LLC, King George, VA U.S.A. http:/ / www.geotrakinc.com/ptt-tracker / PTT-Tracker-User-Guide.pdf (last accessed 31 May 2016).

Gessaman, J.A., M.R. Fuller, P.J. Pekins, And G.E. Duke. 1991. Resting metabolic rate of Golden Eagles, Bald Eagles, and Barred Owls with a tracking transmitter or an equivalent load. Wilson Bulletin 103:261-265.

G.W. Workman, and M.R. Fuller. 1991. Flight performance, energetics and water turnover of tippler pigeons with a harness and dorsal load. Condor 93:546554.

Gregory, A., G. Gordon, And R. Moss. 2003. Impact of nest-trapping and radio-tagging on breeding Golden Eagles Aquila chrysaetos in Argyll, Scotland. Ibis 145:113-119.

HaRmata, A.R. 2015a. Demographic aspects of a Golden Eagle population in southwest Montana. Unpublished report, Contract \#8006.10.025585, National Fish and Wildlife Foundation, Washington, DC U.S.A.

2015b. Status of nesting Golden Eagles in portions of central and southwestern Montana: 2010-2015. Unpublished final report federal grant \# F09ACOO282 to U.S.D.I. Fish and Wildlife Service, Office of Migratory Bird Management, Region 6, Denver, CO U.S.A.

_ And G. Montopoli. 2013. Morphometric sex determination of North American Golden Eagles. Journal of Raptor Research 47:108-116.
And M. Restani. 2015. A notable Golden Eagle encounter. Wingspan 24(1):21.

Hosmer, D.W., S. Lemeshow, and R.X. Sturdivant. 2013. Applied logistic regression. John Wiley and Sons, Inc. Hoboken, NJ U.S.A.

Humphrey, P.S. AND K.C. Parkes. 1959. An approach to the study of molts and plumages. Auk 76:1-31.

HunT, W.G. 1998. Raptor floaters at Moffat's equilibrium. Oikos 82:191-197.

— R.E. Jackman, T.L. Brown, D.E. Driscoll, and L. CuLP. 1996. A population study of Golden Eagles in the Altamont Pass Wind Resource Area; second-year progress report. Report to National Renewable Energy Laboratory Subcontract No. XAT-6-16459-01. Predatory Bird Research Center, Long Marine Laboratory, University of California, Santa Cruz, CA U.S.A.

Jollie, M. 1947. Plumage changes in the Golden Eagle. Auk 64:549-576.

LOCKHART, J.M. AND M.N. KoCHERT. 1980. Effects of visual markers and telemetry devices on the nesting success of Golden Eagles. Special report to the Bird Banding Laboratory, Patuxent, MD U.S.A.

Marzluff, J.M., S.T. KNicK, M.S. VeKasy, L.S. SchueCK, AND T.J. ZARRIELL. 1997b. Spatial use and habitat selection of Golden Eagles in southwestern Idaho. Auk 114:673687.

- M.S. Vekasy, M.N. Kochert, and K. Steenhof. 1997a. Productivity of Golden Eagles wearing backpack radio transmitters. Journal of Raptor Research 31:223227.

Michael, S., B. Gartrell, and S. Hunter. 2013. Humeral remodeling and soft tissue injury of the wings caused by backpack harnesses for radio transmitters in New Zealand Takahē (Porphyrio hochstetteri). Journal of Wildlife Diseases 49:552-559.

Miner, N.R. 1975. Montana Golden Eagle removal and translocation project. Proceedings of Second Great Plains Wildlife Damage Control Workshop 201:155-162.

MoHr, O. 1947. Table of equivalent populations of North American small mammals. American Midland Naturalist 37:223-249.

Montgomery, D.C., E.A. Peck, And G.G. Vining. 2012. Introduction to linear regression analysis, Fifth Ed. John Wiley and Sons, Hoboken, NJ U.S.A.

Moss, H.R., T. Harris, F. Ecke, H. DetTKe, P. SAndstrom, P.H. Bloom, J.W. Kidd, S.E. Thomas, and B. HornFELDT. 2014. Home-range size and examples of postnesting movements for adult Golden Eagles (Aquila chrysaetos) in boreal Sweden. Journal of Raptor Research 48:93-105.

Obrecht, H.H., III, C.J. Pennycuick, and M.R. Fuller. 1988. Wind tunnel experiments to assess the effect of back-mounted radio transmitters on bird body drag. Journal of Experimental Biology 135:265-273.

Peniche, G., R. Vaughan-Higgins, I. Carter, A. Pocknell, D. Simpson, AND A. SAINSBURY. 2011. Long-term health effects of harness-mounted radio transmitters in Red 
Kites (Milvus milvus) in England. Veterinary Record 169:311-317.

Pennycuick, C.J., P.L.F. Fast, N. Ballerstadt, and N. RATtenborg. 2012. The effect of an external transmitter on the drag coefficient of a bird's body, and hence on migration range, and energy reserves after migration. Journal of Ornithology 153:633-644.

ServheEn, C. 1976. Deck-feather molt in Bald and Golden eagles in relation to feather mounting of radio transmitters. Raptor Research 10:58-60.

Stahlecker, D.W., T.H. Johnson, and R.K. Murphy. 2015. Preening behavior and survival of territorial adult Golden Eagles with backpack satellite transmitters. Journal of Raptor Research 49:316-319.

Steenhof, K, K.K. Bates, M.R. Fuller, M.N. Kochert, J.O. MCKinley, AND P.M. LuKaCs. 2006. Effects of radiomarking on Prairie Falcons: attachment failures pro- vide insights about survival. Wildlife Society Bulletin 34:116-126.

U.S. Fish AND Wildlife SERVice (U.S.F.W.S.). 2016. Bald and Golden eagles: population demographics and estimation of sustainable take in the United States, 2016 update. U.S.D.I. Fish and Wildlife Service, Division of Migratory Bird Management, Washington, DC U.S.A.

Watson, J.W., A.A. Duff, And R.W. Davies. 2014. Home range and resource selection by GPS-monitored adult Golden Eagles in the Columbia Plateau ecoregion: implications for wind power development. Journal of Wildlife Management 78:1012-1021.

White, G.C., And K.P. Burnham. 1999. Program MARK: survival estimation from populations of marked animals. Bird Study 46 Supplement:120-138.

Received 13 December 2015; accepted 2 March 2016 